$\mathrm{A} J_{\text {sips }} \mathrm{H}$

Article history :

Received : 31.05.2018

Revised : 12.11.2018

Accepted : 21.11.2018

Author for Correspondence

A. Anburani

Department of Horticulture, Faculty

of Agriculture, Annamalai

University, Annamalainagar,

Chidambaram (T.N.) India

Email : anbumohankarthi2007@

rediffmail.com
THEASIAN JOURNALOF HORTICULTURE

Volume 13 | Issue 2 | December, 2018 | 55-58

Visit us -www.researchjournal.co.in

\section{Effect of water soluble fertilizers on yield and quality parameters in brinjal hybrids (Solanum melongena L.)}

\section{A. Anburani}

ABSTRACT : Field investigation was carried out to study the effect of water soluble fertilizers on yield and quality parameters of brinjal hybrids due to application of various levels of water soluble fertilizer in the University Orchard, Department of Horticulture, Faculty of Agriculture, Annamalai University, Annamalai Nagar. Foliar feeding of water soluble fertilizer NPK (19:19:19) at 0.5 per cent and 1 per cent along with 100 and 75 per cent recommended dose of NPK (200:150:100 $\mathrm{kg} \mathrm{ha}^{-1}$ ) with 5 and 7 sprays, each starting from 30 DAT at 10 days interval, formed twenty treatments in two hybrids. The experimental plots were laid out in Randomized Block Design and replicated thrice. The observations on various yield and quality parameters were recorded and subjected to statistical analysis. The results obtained showed that among the two different concentrations of foliar applied nutrients, 7 sprays of 1 per cent NPK $(19: 19: 19)$ along with 100 per cent recommended dose of fertilizer (200:150:100 $\mathrm{kg} \mathrm{ha}^{-1}$ ) recorded earlier days to 50 per cent flowering, highest number flowers per plant, fruit girth, fruit weight, yield per plant and yield per hectare. The highest quality parameters were also recorded in the same treatment.

KEY WORDS : Brinjal, Water soluble fertilizers, Yield parameter, Quality parameters

HOW TO CITE THIS ARTICLE : Anburani, A. (2018). Effect of water soluble fertilizers on yield and quality parameters in brinjal hybrids (Solanum melongena L.). Asian J. Hort., 13(2) : 55-58, DOI : 10. 15740/HAS/TAJH/13.2/55-58. Copyright@2018 : Hind Agri -Horticultural Society 